\title{
The Scramble for Soutpansberg? The Boers and the partition of Africa in the 1890s
}

Lizé Kriel ${ }^{\bullet}$

\begin{abstract}
Accidents of course happen, but when they occur in clusters and on a global scale some thought needs to be given to the possibility that they had underlying causes which, while still being man-made, were not in themselves, accidental. ${ }^{1}$
\end{abstract}

The most obvious umbrella under which to discuss European conquests of African communities in the late nineteenth century seems to be the "Scramble for Africa" or "the partition of Africa". The literature on these themes ${ }^{2}$ hardly ever includes the Boer conquests of the African communities in the northernmost parts of modern-day South Africa, the former South African Republic. Likewise, the surprisingly dense ${ }^{3}-$ and much of it fairly recently produced $^{4}$ - collection of research outputs on the armed confrontations between the Boers and the Hananwa, the Lobedu and the Venda (to name but a few communities ${ }^{5}$ ) is hardly ever portrayed or explained in a broader African perspective. The motivations and causes are

- Department of History, University of Pretoria.

1. P.J. Cain \& A.G. Hopkins, British imperialism. Innovation and expansion 1688-1914 (London \& New York, 1993), p. 43.

2. See, inter alia, S. Marks, 'Scrambling for South Africa', Journal of African History 23, 1982, pp. 97113; T. Pakenham, The scramble for Africa 1876-1912 (New York, 1991); D. M. Schreuder, The scramble for Southern Africa, 1877-1895: the politics of partition reappraised (Cambridge, 1980); B. Vandervort, Wars of imperial conquest in Africa, 1830-1914 (London, 1998); H.L. Wesseling, Divide and rule: the partition of Africa, 1880-1914 (Westport \& London, 1996);

3. H.W. Grimsehl, 'Onluste in Modjadjiland, 1890-1894' (Argiefjaarboek vir Suid-Afrikaanse Geskiedenis 18/II); L.S. Kruger, 'Die Makgoba-(Magoeba) oorlog 1894-1895' (M.A.-verhandeling, Universiteit van Pretoria, 1955); J.A. Mouton, 'Generaal Piet Joubert in die Transvaalse geskiedenis' (Argiefjaarboek vir Suid-Afrikaanse Geskiedenis 20/I 1957); J.I. Rademeyer, 'Die oorlog teen Magato (M'pefu), 1898', Historiese Studies 5(2), Junie 1944; N.C. Weidemann, 'Die Malaboch-oorlog, 1894', Historiese Studies 7(1), Maart 1946.

4. See T.J. Makhura, 'The Bagananwa polity in the North-Western Transvaal and the South African Republic, c. 1836-1896' (M.A. dissertation, University of Bophuthatswana, 1993); J.W.N. Tempelhoff \& M.H. Nemudzivhadi, 'Riding the storm: Makhado, Venda and the nineteenth century South African Republic, 1864-1895' (Paper presented at the South African Historical Society Biennial Conference, University of Pretoria, 6-9 July 1997); J.W.N. Tempelhoff, 'Die Okkupasiestelsel in die distrik Soutpansberg 1886-1899' (Argiefjaarboek vir Suid-Afrikaanse geskiedenis 60 1997). Tempelhoff recognises the broader context of colonisation throughout Africa, although this is not developed further in his brilliant social history of the Soutpansberg District. T.J. Makhura has done extensive research on the Hananwa. Apart from his dissertation mentioned above, he also produced several articles and conference papers on various aspects of Hananwa interaction with Boers, Britons and missionaries. Two other social scientists focusing on the Hananwa, are anthropologist Johnny van Schalkwyk and literary critic Annekie Joubert. See A. Joubert \& J.A. van Schalkwyk, 'War and remembrance: the power of oral poetry and the politics of Hananwa identity', Journal of Southern African Studies 25(1), March 1999, pp. 29-47.

5. Apart from the Lobedu, the communities on the north eastern escarpment also included the Letswalo/Narene, the Thabina, the Kgaga and the Tlou. See J.S. Bergh, Geskiedenisatlas van SuidAfrika - die vier noordelike provinsies (Pretoria 1999), pp. 201-213. 
confidently anchored somewhere in the politics, economics and mentalities of the South. The question arises whether these researchers, including myself, had been immersed in the turbulent waters of South African historiography so deeply that we failed to appreciate the wider interconnectedness of these events within a broader history of empire. ${ }^{6}$

Or is it truly justifiable to conclude that such a wider context had not existed for the Boers or the Africans of the Soutpansberg District at the time of the late $19^{\text {th }}$ century conquests? Is my "finding" it now merely a response to my own personal awakening to the geographical and ideological entity that is Africa? These questions seem to highlight the inseparable nature of history and historiography: the stories we tell and our reflecting upon these stories as stories. Despite this annoying - or perhaps rather comforting, humbling awareness of the socially constructed, and therefore inevitably flawed and subjective nature of all historical accounts, the historiography of the Boer Campaigns in the Soutpansberg region during the $1890 \mathrm{~s}$ is not the primary concern of this discussion. I would rather regard this exercise as part of an ongoing tinkering at the story/ies of these conquests, but this time against the background of European imperialism during the last quarter of the nineteenth century and the way African polities responded to this challenge.

For the purposes of the discussion, I follow Cain and Hopkins's explanation of British expansion and not the one put forward earlier by Robinson and Gallagher ${ }^{7}$. Cain and Hopkins maintain that the impetus for British overseas expansion should not be sought outside Britain, but in the economic demands of the metropolis itself. For the purposes of this discussion, I therefore regard the notion of peripheral causes for the rapid acceleration in the expansion of formal empire in the last years of the nineteenth century, less plausible than the Cain and Hopkins's argument that such expansion was inspired from the centre of the empire itself ${ }^{8}$ - the centre being London, or Pretoria.

In order to understand what happened in Southern Africa during the 'Scramble for Africa', that spate of mostly violent European acquisitions of territory in Africa between the 1880s and the advent of the First World War in 1914, it seems imperative to explore the notion of secondary empires in more depth. Secondary empires refer to African communities who exploited their partial monopoly over European military technology to colonise their neighbours. ${ }^{9}$ Such an approach would at least start to address the question of the nature of the Boers' colonising identity: Is it acceptable to regard the Boers as a European colonising nation, or do the similarities between (to mention a few) Boer, Asanti, and Egyptian aspirations and predicaments in the shadow of British expansion perhaps suggest a somewhat more complex and hybridic identity oscillating between our fixed preconceptions of the typical coloniser and colonised?

6. Already in the 1960 s G.D. Scholtz pleaded that South African history should be viewed against a broader international background.

7. R. Robinson \& J. Gallagher with A. Denny, Africa and the Victorians. The official mind of imperialism (London, 1981).

8. P.J. Cain \& A.G. Hopkins, British imperialism. Innovation and expansion, 1688-1914, (London \& New York, 1993), pp. 9, 42-43. In the second volume, Crisis and deconstruction, 1914-1990 (London \& New York, 1993), the authors illustrate that the "Gentlemanly Capitalism" which had made London the centre from where British expansion was driven during the nineteenth century, endured deep into the twentieth century. When the Empire finally collapsed, London adapted and the city assumed a new role as intermediary for new powers with far stronger economies.

9. P.Curtin, S. Feierman. L. Thompson \& J. Vansina, African history from earliest times to independence ,(New York, 1995), p. 407. 
For the purpose of scaling down this explorative discussion to a more specific focus, and since the grounds for comparison between the four South African confrontations had at least already been suggested, ${ }^{10}$ I shall approach this discussion as an "asymmetrical" comparison: with strong emphasis on and a more detailed analysis of one South African confrontation as a case tested against the broader corpus of knowledge regarding conflict during the "Scramble". In other words, I shall attempt to shove the Boer-Hananwa confrontation of 1894, comparatively, into the broader context of European campaigns elsewhere in Africa. There are many conquests that can be stated as cases in point, to mention but a few: the British conquests of Somaliland's Habar Awal in 1895, ${ }^{11}$ Benin's Yoruba in $1897,{ }^{12}$ Rhodes's company against the Shona and the Ndebele in what is now Zimbabwe ${ }^{13}$ the Germans against the Herero in modern-day Namibia ${ }^{14}$ and against the Hehe in current Tanzania. ${ }^{15}$

Similarities are not to be spotted only regarding a single aspect of the one campaign and another aspect of the other. In an attempt to indicate that a comparison of crucial factors can be sustained throughout the respective campaigns, I shall restrict myself predominantly to a comparison between the Hananwa of Blouberg and two other specific communities colonised by Britain. Both these selected communities, the Ijebu and the Itsekiri, are part of present-day Nigeria: The Ijebu were the first of the Yoruba communities to be conquered by the British (1892), just as the Hananwa were the first casualty of Boer assertion of power in the Soutpansberg district. The other Nigerian community, the Itsekiri of Ebrohimi, was selected for this comparison because the British campaign against them almost coincided with the Boer campaign against the Hananwa. Both Nana Olomu of Ebrohimi and Kgalusi "Ratshasha" Mmalebôhô, the Hananwa leader, would probably have been willing to put forward a strong case that they were the victims of a smear campaign launched by envious neighbours and exploited by expanding outsider forces.

The focus on British imperialism in this investigation might be a result of my linguistic ignorance of Francophone historiography, the more limited extent of German intervention or the mere magnitude of British colonial acquisitions and writings about these. Hopefully, however, my specific choice of case studies will rather allude to the profound impact Britain had had on Southern Africa and the nineteenth-century Transvaal / South African Republic (ZAR), specifically, in the years preceding and during the Boer conquest of the Soutpansberg District. This limitation to the field under investigation does of course not

10. J.S. Bergh, Geskiedenisatlas van Suid-Afrika - die vier noordelike provinsies (Pretoria 1999); J.W.N. Tempelhoff, 'Die Okkupasiestelsel in die distrik Soutpansberg 1886-1899' (Argiefjaarboek vir SuidAfrikaanse geskiedenis 60 1997); L. Kriel, 'African reaction to white penetration: the Hananwa of Blouberg', Historia 45(1), May 2000, pp. 57-70.

11. A. Adu Boahen (ed.), General history of Africa VII. Africa under colonial domination 1880-1935 (Paris, 1990), p. 44. This was the last of four British expeditions against Somali chiefs unwilling to give up their sovereignty peacefully: In 1886 and again in 1890 campaigns were launched against the Isa; in 1893 against the Habar Gerhaijs; and in 1895, the Habar Awal.

12. E. Isichei, A history of Nigeria (London, 1983), p. 367.

13. P.Curtin, S. Feierman. L. Thompson \& J. Vansina, African history from earliest times to independence ,(New York, 1995), p. 419; T. Pakenham, The scramble for Africa 1876-1912 (New York, 1991), pp. 490-495; T.O. Ranger, Revolt in southern Rhodesia, 1896-7 (London, 1967).

14. R.A. Voeltz, German colonialism and the South West Africa Company, 1884-1914 (Athens, Ohio, 1988),45-54; K. Shillington, History of Africa (London, 1995), pp. 327-329.

15. J.D. Fage \& R. Oliver (general eds.), The Cambridge history of Africa VI, c. 1870-c. 1905, pp. 573574; T.O. Ranger, 'African reaction to the imposition of colonial rule in East and Central Africa' in R.O. Collins (ed.), Problems in the history of colonial Africa, 1860-1960 (Englewood Cliffs, 1970), p. 77. 
rule out the possibility of finding remarkable resemblances between German, Boer and British assumptions and actions during conquest, or in the responses of the Africans under attack. One would eventually also have to admit that late nineteenth-century imperialism was not simply a European affair in Africa, but that it did assume global proportions.

The ZAR will be portrayed both as emulator and casualty of British Imperialism. It will be illustrated that the conflict experienced by South Africa's black people at the hands of the Kruger Government was not unique to the experience of their contemporaries elsewhere in Africa at the hands of British, French, German and Belgian armed forces. It will hopefully also become clear that the Boer state was not the only expanding political entity on the continent to have been usurped by a bigger expanding force during the late $1800 \mathrm{~s}$. The extent to which the conquest of Africa by foreigners still sets the parameters for the discourse on Africa's past, is revealed in the phenomenon that the histories of those conquered by the great European powers are being promoted more strongly and are thus better known than the stories of the minority peoples who were the casualties of secondary empires. This prompts one to ask if the social memory, often being the memory of the group dominating a society in a specific present, is more tolerant towards local oppression, in which they may have played a part, than "foreign" invasion, which affected everyone, often benefiting minorities in the short run. The whiteness of the Boers as an African secondary empire made their exploitation of their "neighbours", the Hananwa and the Lobedu, so much more obtrusive, and the comparison needs to be extended to ascertain whether, to take but two examples, the Asante conquest of the coastal Fante states ${ }^{16}$ and Egyptian expansion into the Sudan, ${ }^{17}$ fall in the same category as the Boers' assertion of their power over the Soutpansberg District. For this hypothesis to be tested properly, a far more intensive investigation needs to be done than what is allowed within the scope of this paper.

16. See J.K. Fynn, 'Ghana-Asante (Ashanti)' in M. Crowder (ed.) West African resistance. The military response to colonial occupation (London, 1971), pp. $25 \& 42$. The Fante states were subjugated by the Asante in the first two decades of the nineteenth century. By 1820 the Asante were regarded as one of the greatest powers in West Africa. On the surface at least, it seems as if one of the key differences between the expansion of Asante power in the 1820s and the extention of Boer power in the $1890 \mathrm{~s}$, lies in the question of British interest in the respective conquered territories. While the Fante's coastal land was crucial to British merchants eager to expand their profits, the British government was also adamant to bring the Asante slave trade to an end. On the other hand, although the British did not approve of Boer treatment of African captives, the Soutpansberg District itself was not nearly as lucrative to Britain as Fante territory. In fact, the British Government did not contest the Boer decision to engage in military conflict with the Hananwa of Mmalebôhô at all.

17. British approval of Egyptian control over the Sudan, (and the joint Anglo-Egyptian artillery and machine-gun attack on this Mahdist state in 1898), probably alludes to stronger similarities between Egypt and the ZAR as secondary empires than the case of Asante considered in the previous footnote. British control over Egyptian financial and political affairs was, especially since 1882, of course far more extensive and formal than in the case of the ZAR. However, the following similarities are at least worthy to take note of: One of the major aims of the so-called Occupation System introduced for the Soutpansberg District in 1886, was, in Kruger's own words, to develop and bring progress to the region. "Ik meen Zoutpansberg zoo ver te brengen dat het ook kan vooruit gaan." (De Volksstem 188611-08, "Reis van ZHEd. De Staatspresident", as quoted in J.W.N. Tempelhoff, 'Die okkupasiestelsel', p. 17.) At least in broad terms, the ambitions and challenges faced by Mohammed Ali during the $1820 \mathrm{~s}$ and 1830s in Egypt, almost foreshadow those of the Kruger Government in the 1880s: As in the case of the ZAR, Mohammed wanted to modernise Egypt, but the methods at his disposal were incompatible with British economic strategy: "Mohammed was a centralising autocrat who favoured state monopolies and protectionism, and had expansionist ambitions of his own, whereas Britain was treading a path towards free trade and minimal government, and needed to create obedient and pacific satellites." P.J. Cain \& A.G. Hopkins, British imperialism, p. 363. 
For the purposes of the current discussion, the focus will remain on the resemblance between Boer and British attitudes and approaches to the conquest of African communities. Special notice will be taken of the discourse of conquest: the words used by the colonisers to exercise their authority and the responses prepared by the colonised to subvert it. The question will thus be asked to which extent the colonized, or soon to be colonized, allowed themselves to be seen through the eyes of their paternalistic conquerors, or whether they contested such inventions.

Before one can commence with a comparison between Boer and British expansionism, the figures who will be presented as the protagonists and antagonists in the Hananwa, Ijebu and Itsekiri communities need some introduction. The Hananwa under Kgalusi Mmalebôhô were attacked by the Boers in June 1894 in an attempt to force the community out of their stronghold in the mountains onto the plain adjacent to the Mogalakwena river. The purpose of the conquest was to extend stronger Boer control over the people so that they could be compelled to contribute to the state income by paying tax and providing labour for farms as well as the gold mines of the Witwatersrand. The campaign against them was the first of a series of expeditions against African communities in the Soutpansberg district still regarding themselves as independent political entities. The manon-the-spot who would benefit from Hananwa subjugation (because of the small percentage of the tax collections that could legally - and clandestinely - go into his own pocket) was Commissioner Barend Vorster sr. The Boer Commander of the military campaign was Commandant-General Piet Joubert, leader of burgher force of the ZAR. ${ }^{18}$

The first African conquest that will be compared with the Boer-Hananwa conflict, concerns the Ijebu of West Africa. Their capital, Ijebu Ode, was attacked from the British colony of Lagos in May 1892. This was the beginning of the rapid extension of British rule over the Yoruba and the eventual proclamation of the Lagos protectorate in 1906. Britain saw the Ijebu as a hindrance for direct trade between their colony at Lagos and the Yoruba communities deeper into the interior. They wanted to put an end to internal wars and politics stifling the flow of trade to the coast. British men-on-the-spot active in the prelude to as well as the conquest of Ijebu Ode, were a certain Millson, the assistant Colonial Secretary, and the newly appointed Governor of Lagos, Gilbert Carter. ${ }^{19}$

The second case to be compared with the Hananwa, is that of the Itsekiri traders of another nineteenth-century stronghold in west Africa: Ebrohimi. British interest in Ebrohimi, the stronghold of Nana, a highly successful but notorious Itsekiri trader, was, not surprisingly, a stronger share in and control over trade in the area dominated by Nana. In this case, the men-on-the-spot were the Vice-Consul of Benin river, Henry Lionel Gallwey, and the Consul General himself, Sir Claude Macdonald, but for the duration of the hostilities, more specifically the acting Consul-General, Ralph Moor. Rear Admiral F.G. Bedford,

18. J.S. Bergh (ed.), Geskiedenisatlas van Suid-Afrika: die vier noordelike provinsies (Pretoria, 1999), pp. 201-213; L. Kriel, 'African reaction to white penetration', Historia 45(1), May 2000, pp 57-70; South African National Archives: TA: SS. 4700, R.2004/95: Verslag of Algemeen Overzicht van den Commandant-Generaal van den gevoerden krijg tegen de oproerige kafferstammen van Malaboch (te Blauwberg), Seleboel, Magoeba, Mahoepa en anderen, wonende in die Lage Velden van het district Zoutpansberg.

19. E. Isichei, A history of Nigeria (London, 1983), p. 365; R. Smith, Nigeria-Ijebu, in M. Crowder (ed.) West African resistance. The military response to colonial occupation (London, 1971), pp.170-204; J.D. Fage \& R. Oliver (general eds.), The Cambridge history of Africa VI, c. 1870-c. 1905, pp. 270271. 
commander of the British African squadron, personally took over the command of the expedition against Nana on 18 September $1894 .^{20}$

While it took the British less than a month to complete the whole expedition against the Ijebu, the conquest of Mmalebôhô's mountain stronghold took approximately three months. Nana's fortified city in the swamps up the Brohemie Creek was taken within two months.

\section{The men-on-the-spot}

'If they were active; it is because they had been given a mandate from the centre.'21

It is significant that the African historians compiling contributions for the 1971 publication West African Resistance, hardly even considered Robinson and Gallagher's diction that the causes of the conquests of the various African peoples had to be sought "on the spot", in the dynamics of African events themselves. After illustrating local tensions, including rivalry between Nana and less powerful traders (which reminds one a little of the discord between Mmalebôhô and Kibi, his less powerful rival at Blouberg ${ }^{22}$ ) Obaro Ikime moves on to illuminate "British imperial ambitions in West Africa" and territorial claims which, according to him, had to be "made good" in the wake of the increasing French and German competition of the $1890 \mathrm{~s}^{23}$ Whether these few sentences indeed provide the core of an explanation for the remarkable surge in colonial military expeditions in the $1890 \mathrm{~s}$, is of course debateable. At least it indicates that Cain and Hopkins's argument, of European ambitions being the driving force behind European acquisitions of territory in Africa, is a concession to sentiments expressed in African historiography even before the commencement of their project on British imperialism.

Boer aggression in the Soutpansberg district can be explained along the same lines: The Boers had lost their independence to the British in 1877 because they would not willingly join a pro-British South African federation. The Boers' apparent inability to control the African communities supposedly under their jurisdiction was cited by Britain as an important justification for their annexation of the Transvaal. Almost immediately after reclaiming their independence from Britain in 1881, Boer actions started reflecting a challenge to this perception. After the subjugation of the Ndzundza Ndebele in 1882-1883, several more Boer campaigns against African communities followed. ${ }^{24}$ In 1886 , eager to prove their suzerainty to the British and in reaction to British and German competition for control over more land in southern Africa, the Boers actively engaged in a similar strategy as their competition. With the so-called "Occupation System", they embarked upon a new expansive policy of modernisation, progress and stronger control over the Soutpansberg area. $^{25}$

20. O. Ikime, Nigeria-Ebrohimi in M. Crowder (ed.) West African resistance. The military response to colonial occupation (London, 1971), pp. 205-232.

21. P.J. Cain \& A.G. Hopkins, British imperialism. Innovation and expansion 1688-1914 (London \& New York, 1993).

22. C. Sonntag, (ed. K. Sonntag), My friend Maleboch, chief of the Blue Mountains, p. 10.

23. O. Ikime, Nigeria-Ebrohimi in M. Crowder (ed.) West African resistance. The military response to colonial occupation (London, 1971), p. 213.

24. J.S. Bergh (ed.) Geskiedenisatlas van Suid-Afrika ...

25. J.W.N. Tempelhoff, 'Die okkupasiestelsel', pp. $12 \& 17$. Even before the implementation of the Occupation System in the Soutpansberg in 1886 
Had it not been for an awareness of this broader policy framework, the student of the Boer-Hananwa War, as of almost any other war of colonial conquest, could easily have concluded that the initiative for the conquests had come from local officials who had to work very hard to persuade the central government to intervene and assume control over still independently-acting peoples on the periphery.

It does however seem that men-on-the-spot could at least have had an influence of the chronology of conquests in a particular area. An active missionary or local official could draw attention to a certain community as a convenient inroad into a greater region. For example: The impression in the Pretoria press was that the Venda, and not the Hananwa, were the Africans who actually posed a threat to Boer supremacy in the Soutpansberg. ${ }^{26}$ Furthermore, far more white farmers were residing on the north-eastern escarpment than in Hananwa territory. These farmers, in the area of rulers Modjadji, Tsolobolo, Makgoba and Mahoepa, were living under continual threat of Africans retaliating against incursions on their land. ${ }^{27}$ However, the 'softer target,' the Hananwa, were attacked by the Boer forces first. The fact that the Boer military commander himself considered Mmalebôhô the easiest of several potential targets, illustrates that man-on-the-spot Barend Vorster's incessant pleas for intervention in his back yard ${ }^{28}$ was not the only, probably not even the actual, reason why this community was attacked first. One should, however, not rule out the ingenuity of a local official like Vorster in playing the expansion game to his own hand: The financial gain that would have come out of a defeated, law-abiding, tax-paying Hananwa community for him personally, should not be underestimated. ${ }^{29}$

A similar case out of West Africa is that of the Ijebu, who fell prey to the British in 1892, although their neighbours, the Egba, were "at least equally to blame" for hindering the flow of Yoruba trade from the interior the British trading centre Lagos, at the coast. According to Robert Smith, the fact that the Ijebu were regarded as the "principle obstacle to the achievement of British objectives" 30 can be attributed to the Anglican missionaries" complaints and the way in which local colonial officials, particularly Millson and Carter, put these to use in their reports to London.

26. The Press, 1894-06-15: "Malaboch [Mmalebôhô] is so small and unimportant a chief that it has been generally felt that it does not matter much what he does. It is the attitude of Magato [Makhado] which is important."

27. J.W.N Tempelhoff, 'Die okkupasistelsel', pp. 257 \& 261; J.S. Bergh (ed.) Geskiedenisatlas van SuidAfrika, pp. 201-213.

28. TA: SS. 4140 , R. $17552 / 90$, pp. 65-104: Waarnemende Landdrost Pietersburg zendt rapport van Commissaris Vorster waarin hij meldt van botsingen die hij had bij de vordering van belasting bij Kapitein Malleboch, 1890-12-19; TA: SS. 4140, R. 2696/92. SR. 187/92, pp. 105-109: Commissaris Kalkbank klaagt over het gedrag van Kapitein Malebock die weigert Makera die van hem beesten in bezit heeft, uitteleveren, 1892-02-08; TA: SS. 4140, R. 1965/94, pp. 20-64: Commissaris Naturellen Kalkbank. Rapport omtrent eene expeditie door hem ondernomen tegen de naturellen woonachtig te Blauwberg, 1894-01-17; TA: SS. 4209, R. 3863/94, SR. 133/94, pp. 16-18: Commissaris Naturellen Kalkbank - Superintendent van Naturellen, Pretoria, 1894-01-15; TAB: SS. 4413, R. 8813/94, CR. 1417/94, p. 78: Commissaris Vorster - Commandant-Generaal, 1894-05-06.

29. According to ZAR law, a commissioner like Vorster was entitled to five percent of all the taxes he collected. Furthermore, it was not an uncommon practice for commissioners to estimate the value of cattle far lower than the market prize when seizing livestock from Africans who had no cash to pay their taxes. See Law no. 6, 1880, published in F. Jeppe (compiler), Locale wetten ... 1849-1885 ..., p. 749; C. Sonntag (ed. K. Sonntag), My friend Maleboch ..., p. 34; P. Delius, Power and profit in the Eastern Transvaal, W. Beinhart, P. Delius \& S. Trapido (eds.), Putting a plough to the ground. Accumulation and dispossession in rural South Africa, 1850-1930 (Johannesburg, 1986), pp. 176-217.

30. R. Smith, Nigeria-Ijebu, in M. Crowder (ed.) West African resistance. The military response to colonial occupation (London, 1971), p. 176. 
Whether the coloniser was Boer or British, the dynamics between officials in the centre (London or Pretoria) and on the periphery (Lagos and Pietersburg) were very much alike: In the case of the Hananwa, local officials Barend Vorster (Commissioner) and G.G. Munnik (Landdrost / Magistrate in Pietersburg) worked hand-in-glove with Berlin missionary Carl Stech to promote an image of the Hananwa similar to that of the Ijebu portrayed by the Anglican missionaries, ${ }^{31}$ Millson and Carter. Compare the remarks by the British and Boer officials:

Millson (14 February 1890):

The difficulties put in the way of the realisation of [this] prosperity alike for Lagos and the land of the Yoruba lie solely at the doors of the king and people of Jebu ... ${ }^{32}$

Vorster (15 January 1894):

De naturellen aan Blauwberg vooral, zijn ons district tot groot nadeel. Gedurig wordt er vee gestolen en wordt naar Blauberg gevoerd waar den vee in veiligheid zijn, en de dieven door de Kapitein beschermd worden. ${ }^{33}$

Munnik (25 April 1894):

Ik heb de grootste vertrouwen in Cmdt Vorster en denk niet dat hij buiten zijn instructies handelen zal en ik neem deze geleenheid waar mijne sienswijze aan Ued Gest bekend te stellen dat de tijd geheel en al voorbij is om de naturellen en voornamelijk Malaboch met een klein politiemacht hetzij blank of gekleurd te trachten te intimideren ... ${ }^{34}$

The impression the reader gets from the two sets of correspondence, is that Governor Carter (1892) and Commissioner Vorster (1894) both had been "wearing down" superiors (British Colonial Secretary Knutsford and Boer Commandant-General Piet Joubert respectively) with pleas for intervention in the peripheral areas under their authority: In both cases it seems as if local conditions on the periphery of empire, a la Robinson and Gallagher, had necessitated intervention from a reluctant centre (Pretoria and London). In both cases, however, the assertion of their power in the particular regions in Africa did fall into the greater planning of the British and the Boer Government. The peaceful attainment of the

31. In the case of the Ijebu, the local Anglican missionaries played a significant role in drawing the attention of the British Colonial Office. Their protests against the Ijebu closing the roads to the coast after an agreement to the contrary had just been reached, were promptly passed on to Whitehall by the Lagos Administration. R. Smith, Nigeria-Ijebu, in M. Crowder (ed.) West African resistance. The military response to colonial occupation (London, 1971), p. 177.

32. Public Record Office, London: CO 879/33, as quoted by Smith, Nigeria-Ijebu, in M. Crowder (ed.) West African resistance. The military response to colonial occupation (London, 1971), p. 176.

33. TA: SS. 4209, R. 3863/94, SR. 133/94, pp. 16-18: Commissaris Naturellen Kalkbank - Superintendent van Naturellen, Pretoria, 1894-01-15. "The blacks of Blouberg in particular, are a great detriment to our district. All the time cattle are being stolen and taken to the safety of the mountains, where the thieves are protected by the chief." Free translation L.K.

34. TA: SS. 4140, R. 1965/94, CR. 1200/94, SR. 904/94, pp. 62-64: Landdrost, Pietersburg Commandant-Generaal, Pretoria, 1894-04-25. I have the greatest confidence in Cmdt Vorster and I doubt if he will act contrary to his instructions and I make use of this opportunity to inform your excellency of my viewpoint that the time has run out for trying to intimidate the Africans and specifically Mmalebôhô with a small police force - whether white or black." Free translation L.K.

35. R. Smith, 'Nigeria-Ijebu' in M. Crowder (ed.) West African resistance. The military response to colonial occupation (London, 1971), p. 177. 
subservience of a region was preferable, but both governments would rather divert to military conquest than letting the regions run out of their control.

\section{The coloniser justifying a military campaign}

It is curious that both the Boers and the British presented themselves as the injured parties in the peripheral crises that were mostly their own making. However, had they no interests in the area, they would have had no crisis with which to deal. Take the following example: In May 1891, Britain's Acting Governor at Lagos, a certain Denton, visited the Ijebu to demand the opening up of the trade routes running through their territory so that the British could increase their benefits from this trade between the interior of Yorubaland and the coast. The Ijebu showed their indignation by refusing to accept Denton's customary presents and denying him passage further north-east through their territory. Ijebu behaviour was on its turn greeted with British indignation. The incident was reported to Whitehall, from where instruction was given that a full apology, as well as "free and unmolested" passage through their territory for "all traders and other persons" should be demanded from the Ijebu. ${ }^{36}$

In the previous year a similar crisis was concocted by Commissioner Barend Vorster at Blouberg. He visited Mmalebôhô with the purpose of demanding payment of taxes and the making of a sensus among the Hananwa leader's subjects. Mmalebôhô's indignation at this challenge to his authority in his own realm was interpreted by Vorster and his small contingent as threatening hostility. As in the case with the ljebu, a condemning report on the Hananwa was sent to Pretoria:

Er blywe dus voor my geene aanbeveling om genade voor hem - Doch ik zou ten strengste aanbevelen om in de beginne van den maand April 1891 eene aanvang zal gemaakt worden om deze Staats Rebel tot hunnen picht te bringen. $^{37}$

Also in the case of Nana from Ebrohimi, the African leader was made the culprit should the expansionist force's profits in the particular region not be satisfactory. The 1894 British expedition against Nana was justified by accusing him of "causing a breach of peace [whose peace?], of breaking his treaty obligations [a treaty from which only Britain benefited] and engaging in slave trade [as if the British themselves were not involved in just a new form of human manipulation]., 38

Note, how in all the above instances, the crisis was engendered by the men-on-thespot in the act of trying to implement instructions from the centre (London and Pretoria) on the periphery of the British and Boer (secondary) empires respectively.

In compiling an argument to explain why it was necessary to assert their power in a troubled region (either by force or the threat of using force), the colonial officials portrayed themselves as the benevolent interveners: rescuing weaker African factions from their oppressors. In 1892 Governor Carter of Lagos was convinced that "an important section of

36. R. Smith, 'Nigeria-Ijebu' in M. Crowder (ed.) West African resistance. The military response to colonial occupation (London, 1971), p. 176.

37. TA: SS. 4140, R. 17552/90, SR. 813/90, p. 79: Rapport van Commissaris Vorster, 1890-12-19. "Therefore I cannot advise that he should be shown any mercy. I rather strongly recommend that an attempt to subjugate these rebels against the state should commence beginning of April 1891." Free translation L.K.

38. O. Ikime, 'Nigeria-Ebrohimi' in M. Crowder (ed.) West African resistance. The military response to colonial occupation (London, 1971), pp. 215-216. 
the Ijebu, the Remo, were anxious to escape from the yoke of Ijebu Ode and were well disposed towards his own government." ${ }^{39}$ Two years later, at Blouberg in the northern Transvaal, Mmalebôhô was held responsible for intimidating the followers of his neighbours, Mapene and Kibi, who, the Boers claimed, were actually quite anxious to submit to Boer authority and pay their taxes. ${ }^{40}$ Approximately at the same time in West Africa, in June 1894, the British took up the cause of some Urhobo people reportedly seized by the fighters of Nana, the Itsekiri leader whose power they were adamant to break. ${ }^{41}$

The mentality of the colonisers in the centre and "on the spot" was such that they believed that the extension of their authority over African communities was justified. The colonisers needed the input of the colonised; they needed their trade, their labour, their resources. From the coloniser's point of view, the co-operation of the African leaders made perfect sense. Therefore the Hananwa, the Ijebu and Nana's Itsekiri were scolded for not behaving according to the role invented for them by the coloniser. In the mind of the coloniser, the African was already cast in the role of the subordinate long before the Africans themselves had come to accept it. This subordinate role designed for Africans, seems to have been so obvious to the colonisers that they could not comprehend how much persuasion it would take also to make the Africans see things their way. It is remarkable how many times both the Boers and the British assumed that the mere threat of violent subjugation would be enough to convince an African community to capitulate.

In 1892 Governor Carter, comparing the "pusillanimous Jebu [Ijebu]' with the "warlike Ibadans", informed the British Colonial Office from Lagos that he did not "anticipate any difficulty from a military point of view". ${ }^{42}$ Two years later, the supposedly feeble Hananwa of Mmalebôhô were contrasted with the supposedly war loving Zulu and Swazi in a similar manner in the editorial of a Pretoria newspaper. ${ }^{43}$ According to Landdrost Munnik in Pietersburg, all that was needed to persuade the Hananwa to start paying taxes to the ZAR, was a show of force by a significant number of burghers. ${ }^{44}$ Like Munnik in the ZAR, Ralph Moor, a month of two later in Yorubaland, also seems to have believed that the besieged Nana and his followers would capitulate before the threat of full scale military action needed to be realized. ${ }^{45}$

If threats alone were ignored and the colonisers actually had to engage in conflict, they still believed that their willingness to engage in a military confrontation with one community, would serve as enough warning for neighbouring communities to succumb peacefully. So the campaign against the Ijebu in 1892 was also considered a warning lesson for the Egba. On this occasion, the warning seems to have worked, but the Boers' war of

39. R. Smith, 'Nigeria-Ijebu' in M. Crowder (ed.) West African resistance. The military response to colonial occupation (London, 1971), p. 178.

40. C. Sonntag (ed. K. Sonntag), My friend Maleboch ..., p. 12; TA:

41. O. Ikime, 'Nigeria-Ebrohimi' in M. Crowder (ed.) West African resistance. The military response to colonial occupation (London, 1971), pp. 215-216.

42. R. Smith, 'Nigeria-Ijebu' in M. Crowder (ed.) West African resistance. The military response to colonial occupation (London, 1971), p. 178.

43. The Press, 1894-06-28: "Fortunately, they are not very brave, and are in fact little more than a crowd of kitchen boys who are likely to precipitately abandon impregnable positions from shear panic."

44. TA: SS. 4140, R. 1965/94, CR. 1200/94, SR. 904/94, pp. 62-64: Landdrost, Pietersburg Commandant-Generaal, Pretoria, 1894-04-25. “... en dat het vereischt spoedigste en goedkoopste om deze zaak tot een eind te brengen zou zijn om met een behoorlijk aantal burgers te gaan wanneer ik geen twyfel heb of dat Malaboch zal betalen ..."

45. O. Ikime, 'Nigeria-Ebrohimi' in M. Crowder (ed.) West African resistance. The military response to colonial occupation (London, 1971), pp. 218. 
1894 against Mmalebôhô did not have the desired effect upon the African rulers on the northeastern escarpment. After Tsolobolo, Makgoba and Mahoepa had also been subjugated by force, the Boers still hoped that their (by now multiple example) would serve as a warning for the Venda leader, Makhado. The Venda remamained unconquered until 1898; they eventually turned out to be the last African community to have been forcefully subjugated by the Boers - before they themselves were conquered by the British. ${ }^{46}$

Just as unlikely as it was that the Ijebu would actually give in to the British demand that "all traders and other persons" were to be allowed free passage over their land indefinitely, it was improbable that Mmalebôhô and Nana would accept that they had lost their authority over their people simply because the Boers or the British demanded it. On 6 June 1894, Commandant-General Piet Joubert sent the following letter to Mmalebôhô:

Know, Maleboch, that I can no longer recognize you as Chief of Blaauwberg. By your disobedience you have lost this privilege. I am sorry to say that through this disobedience you have also led your people astray. I herewith inform you that you are no longer Chief of this people, but I. I desire you to communicate this to all your people. ${ }^{47}$

This message almost echoed the words from a letter received by Nana of Ebrohimi, in April 1894: "as the British Government was already well established in the area, Nana was no longer to regard himself as the Governor of the River and so head of the Itsekiri people, but only as head of his own family." 48

Despite the warning by missionary Christoph Sonntag, that "the surest way to drive a chief to wage a war of sheer desperation to the bitter end was to tell him that he had already been divested of his dignity as the leader of his people," 49 it seems as if, at least initially, neither Mmalebôhô nor Nana took the decisions taken by the colonisers about their futures too seriously. Mmalebôhô still believed that that he could appease the Boers with a gift of with twenty pounds and a white ox. Nana too, hoped that he "could work out a modus vivendi with the British which would leave him in the position he had occupied since his father's death in 1883 [as Governor of Benin river.]"50

It would thus be wrong to conclude that the African rulers were eager to engage in a war with the colonisers. Initially, like the European officials, the African leaders also did not seem to anticipate a military showdown (it were probably only the most vengeful men-onthe-spot and the most boisterous young African warriors who would have dared to pick a fight - one shall remember that Lobengula skilfully reigned in his young warriors' hunger to go and wash their spears in white blood. $)^{51}$ Still very confident of their own autonomy, the African leaders at first assumed that the high standing they enjoyed in the eyes of their subordinates, would also apply in the presence of the Europeans. They must have assumed

46. R. Smith, 'Nigeria-Ijebu' in M. Crowder (ed.) West African resistance. The military response to colonial occupation (London, 1971), pp. 179 \& 194; TA: SSA. 2, RA. 14/94, pp. 36-38, CommandantGeneraal - Staatspresident, 1894-06-30. . "Wanneer deze laatste kaffers [Tsolobolo, Makgoba, Mahoepa] ook tot onderwerping gebracht zijn, zal Magato zich mogelijk ten goede bezinnen en wanneer hij de krijgsmacht gereed ziet, aan de eischen der Regering voldaan." Underlining K.R. Keizer

47. C. Sonntag (ed. K. Sonntag), My friend Maleboch ...,p. 49.

48. O. Ikime, 'Nigeria-Ebrohimi' in M. Crowder (ed.) West African resistance. The military response to colonial occupation (London, 1971), pp. 215.

49. C. Sonntag (ed. K. Sonntag), My friend Maleboch ..., p. 49.

50. O. Ikime, 'Nigeria-Ebrohimi' in M. Crowder (ed.) West African resistance. The military response to colonial occupation (London, 1971), pp. 215.

51. T. Pakenham, The scramble for Africa 1876-1912 (New York, 1991), pp. 490-495. 
that they had the stature to negotiate a settlement with the whites. Had they been aware of the multitude of Boer, British, French and German military conquests taking place all over Africa at the time, they would have realised sooner that they were trying to resist an unstoppable wave.

\section{Ultimatums: to be given a choice that leaves no other choice}

Taking for granted that integration into the Boer or British system (on Boer and British terms respectively) was to the benefit of all, it seems as if the colonisers could not perceive how much the African communities were to forfeit under Boer or British domination. It was not even thought of to put into question the "subject" status of a community regarded from the centre as falling within the realm of the interests of the empire. It was taken for granted that those who could contribute to the wealth, prosperity, status and power of the empire, had to be available and willing to do so - even more, that it would be in their best interest. This probably also explains why the British and the Boers were so surprised at the stiff resistance put up by these communities: Overestimating the power they wielded over what they regarded as inferior peoples; the colonisers failed to appreciate that the African leaders cherished their independence and autonomy just as much as the colonisers valued their own. A ruler who was reluctant or defiant upon the proposal of incorporation into the imperial system, was regarded as foolhardy, troublesome and dangerous. This highlights the predicament of an African leader when he eventually realised that whichever way he responded to a Boer or a British ultimatum, he had already been earmarked to be disposed of. What was presented by the colonisers as a generous choice between negotiations and war, was not perceived by the Africans as much of choice at all. Hargraves summarised the situation poignantly in his discussion of the dual between Samori Touré of Tukolor and the French imperial powers:

Samori's case thus hardly supports the view of Professor Oliver and Fage that 'nothing was to be gained by resistance and much by negotiation', nothing that he [the African ruler] held important could have been permanently gained by either method. ${ }^{52}$

The tactics used by both Mmalebôhô and Nana to tease out the actual intentions of the colonisers' negotiations with them, are worthy of comparison. The exchange of messages between Mmalebôhô and Commisioner Vorster (later Commandant-General Joubert) was very similar to the communication between Nana and British acting Consul-General Ralph Moor in June of the same year. This illustrates just how thinly veiled the colonisers' attempts were to get control over their opposition by seizing their rulers. It is also significant how the colonisers and the colonised alike regarded the annihilation of one specific leading individual as the symbolic defeat of a particular community. The collective memory of the respective communities would later reinforce this importance attached to the charisma of a single figure.

Upon receiving a message from Ralph Moore summoning him to the vice-consulate for discussions, Nana replied with a host of excuses; anticipating that this would urge the colonial official to reveal more of his intentions: "there had been three recent deaths in his family and ... his brother was even then seriously ill. He found it impossible to travel in the circumstances but would send his trusted messenger, Tonwe, to represent him at any

52. J.D. Hargreaves, 'African reaction to the imposition of colonial rule in West Africa' in R.O. Collins, Problems in the history of colonial Africa 1860-1960 (Englewood Cliffs, 1970), p. 64. The reference to Oliver and Fage is from: R. Oliver \& J.D. Fage, A short history of Africa (Harmondsworth, 1964), pp. 202-203. 
discussions the consul might wish to hold." 53 Offering to send a substitute, Nana ascertained whether the British were serious about discussions, or whether they were looking for an opportunity to detain him and replace his authority with their own. Moor was indeed not willing to negotiate with an intermediary and now urged Nana to attend a meeting for the discussion of "matters of great importance." 54 According to Ikime, Nana "replied in the same vein as to the previous letter." 55 The vagueness of the reference to matters supposedly so very important, must have signalled to Nana that the only matter of importance to the British was to get hold of him personally.

Mmalebôhô had already been "invited" to Commissioner Vorster's residence in April 1894. ${ }^{56}$ Mmalebôhô's reply was very diplomatic:

Please ask the commissioner to come closer so that we can better discuss the whole matter. He has come to pay me a visit [thereby underlining that the Boer official had entered territory over which the Hananwa believed he had no jurisdiction], so why does he stand still so far away in the fields? ${ }^{57}$

By postponing an actual face-to-face meeting with the Boer leaders, Mmalebôhô eventually managed to bring them so far to admit what their actual intention with the Hananwa was without the $\mathrm{kgosi}$ having had to risk his freedom in order to confirm his suspicions. They were not only to pay their taxes and have a census made; within eight days they were also to move down from their mountain stronghold to be resettled on the plain along the Mogalakwena river. Although the Boer General tried to create the impression that the order for the people to evict the mountains was punishent for their resistance, ${ }^{58} \mathrm{ZAR}$ government documentation clearly indicates that the reserve along the Mogalakwena had long since been earmarked for the Hananwa. ${ }^{59}$ As Mmalebôhô himself put it: "The commissioner does not want taxes, he wants my head." 60

Mmalebôhô, as Nana, did not really have any other choice but to resist the invaders by force. Considering the confidence they had in their autonomous position, as well as the fact that they had been accumulating weapons over a significant period of time, ${ }^{61}$ they must

53. O. Ikime, 'Nigeria-Ebrohimi' in M. Crowder (ed.) West African resistance. The military response to colonial occupation (London, 1971), p. 216.

54. F.O. 2/64, Moor to Nana, 24 June 1894, as quoted by O. Ikime, 'Nigeria-Ebrohimi' in M. Crowder (ed.) West African resistance. The military response to colonial occupation (London, 1971), pp. 216.

55. O. Ikime, 'Nigeria-Ebrohimi' in M. Crowder (ed.) West African resistance. The military response to colonial occupation (London, 1971), pp. 216.

56. C. Sonntag (ed. K. Sonntag), My friend Maleboch, p. 20.

57. C. Sonntag (ed. K. Sonntag), My friend Maleboch, p. 23.

58. C. Sonntag (ed. K. Sonntag), My friend Maleboch, p. 33.

59. T.J. Makhura, The Bagananwa polity ..., p. 143; TA: SS. R. 4678/88, SR. 379/88: Vorster Superintendent van Naturellen, 1888-05-14.

60. C. Sonntag (ed. K. Sonntag), My friend Maleboch, p. 30.

61. T.J. Makhura, The Bagananwa polity, pp. 156-157 explains how the Hananwa had been acquainted with fire-arms for decades by the time the Boers launched their military expedition against them. They also made use of an extensive and versatile network to get hold of fire-arms. Firstly, several Hananwa had been employed by the Boers as hunters as early as the $1850 \mathrm{~s}$; secondly, the Hananwa obtained rifles via Lobedu and Venda middllemen from Portuguese traders at Delagoa Bay; thirdly, they dealt directly with African traders in present-day Botswana and illegal European traders in the ZAR; fourthly, some missionaries were suspected of training Africans in the use and repair of fire-arms. In the final instance, the migrant labour system provided a cash income for weapon transactions. During the 1894 campaign, the Boers were surprised to observe some Hananwa warriors with very modern rifles. (The Press, 1894-07-28) 
have believed that, by fighting, they still stood a chance to defend their independence. In fact, the Ijebu believed that they stood a very good chance to "repel any invasion." 62 At any rate, by not resisting the invaders, the African leaders would give up everything they stood for immediately: their dignity, their power over their people, almost certainly their freedom too.

\section{Why did the Africans lose?}

The reason why all the African communities lost their wars of resistance, has been put forward by numerous scholars and it only remains here to test whether the case study of the Boers against the Hananwa confirms, or calls for a reconsideration of these explanations.

Like the British, the Boers had better weapons than the Africans, including the dreaded Maxim gun. ${ }^{63}$ This was probably the single most decisive factor in the Boer victory over the Hananwa. The point was also raised that the Hananwa were far outnumbered by the Boers and their compatriots. ${ }^{64}$ Yet, while the Ijebu outnumbered the British invading force ten to one, they were convincingly defeated. ${ }^{65}$ It seems as if fire-power, much more than

According to Smith, most of the Ijebu warriors must have been equipped with some kind of firearm. Several may still have used flint-lock muskets (Dane-guns, as they were called along the west coast), but considering that, since the early $1800 \mathrm{~s}$, the Ijebu had taken the lead among the Yoruba in procuring modern weapons, and taking into account that breech-loading rifles were available in their part of West Africa since the 1870 s, it is probable that most of the Ijebu riflemen were equipped with Snider rifles A large quantity of rifle ammunition and gun powder was found in the Ijebu camp after their defeat. See R. Smith, 'Nigeria-Ijebu' in M. Crowder (ed.) West African resistance. The military response to colonial occupation (London, 1971), p. 181.

Nana had been engaged in numerous one-day battles with trading rivals prior to the British expedition against him. His warriors had access to modern weapons, including rifles, machine-guns and cannons, but their inexperience in handling this equipment, obtained mostly from British traders, seriously curbed the efficiency thereof. See O. Ikime, 'Nigeria-Ebrohimi' in M. Crowder (ed.) West African resistance. The military response to colonial occupation (London, 1971), pp. 214, 226-228.

62. R. Smith, 'Nigeria-Ijebu' in M. Crowder (ed.) West African resistance. The military response to colonial occupation (London, 1971), p. 179.

63. According to R. Smith, 'Nigeria-Ijebu' in M. Crowder (ed.) West African resistance. The military response to colonial occupation (London, 1971), p. 179 "[t] he armamament of the [invading force against the [jebu] was as heterogeneous as its composition": Gold Coast constabulary - Martini Henry rifles; Lagos constabulary - Sniders; a West Indian company sent from Sierra Leone: - MartiniHenry's; Ibadan volunteers - 'Dane guns' or Sniders. Artillery allotted for the expedition comprised: Three seven-pounder guns, one Maxim machine-gun, two Nordenfelt machine guns and three rocket troughs.

In subjugating the Itsekiri of Nana, Ralph Moor had three battle ships and all the men and military resources of the Niger Coast Protectorate at his disposal. The artillery used in the capture if Ebrohimi was similar to the guns used against the Ijebu: seven pounder guns, axim guns and rockets. (O. Ikime, 'Nigeria-Ebrohimi' in M. Crowder (ed.) West African resistance. The military response to colonial occupation (London, 1971), pp. 222-226.

For the expedition against the Hananwa, the ZAR State Artillery was equipped with one $3.7 \mathrm{~cm}$ quickfiring gun, two Martini Henry maxims, four $6.5 \mathrm{~cm}$ Krupp mountain guns and two $7.5 \mathrm{~cm}$ Krupp guns, all back loaders, although model 1870. (S.P.E. Trichardt, Geschiedenis, werken en streven van ... luitenant kolonel der vroegere Staats-Artillerie Z.A.R. door hemzelve beschreven (ed. O.J.O. Ferreira) Raad vir Geesteswetenskaplike Navorsing Bronnepublikasie 3 (Pretoria, 1975), p. 59)

64. T.J. Makhura, The Bagananwa polity ..., p. 163: In total, approximately 4000 whites and 2000 African mercenaries participated in the siege of Mmalebôhô's stronghold; which was occupied by approximately 2000 Hananwa men, women and children.

65. R. Smith, 'Nigeria-Ijebu' in M. Crowder (ed.) West African resistance. The military response to colonial occupation (London, 1971), p. 192. 
physical numbers, was the crucial factor in wars of this kind, although, in the case of the Boers against the Hananwa, one has to concede that the Boer tactic of entrenching the Hananwa at the top of their mountain fastness and thirsting them out by cutting off their water supply, could only succeed with the use of an army of significant size. ${ }^{66}$

Unlike the African communities in what is today Nigeria, ${ }^{67}$ the Hananwa shots earned Boer respect for their accuracy. ${ }^{68}$ Especially Mmalebôhô's own good marksmanship could hardly be ignored. ${ }^{69}$. It was also suggested that the imperial forces were normally much better organised than the African fighters. In this instance the correlation between the British troops fighting the Ijebu and the Iksekiri, and the Boers commandeered to fight Mmalebôhô, is not very apt. The Boer forces were notorious for their lack of military discipline and it was a self-proclaimed virtue of the burgher force that they would rather take care of their own safety and prolong the campaign by waiting for the enemy to expose themselves than trying to display courage in an expedition against an African chief. ${ }^{70}$

A much more significant correlation is to be found in the role played by "friendly blacks" in Boer as well as British expeditions in the 1890s. The conquests undertaken in the last decade of the nineteenth century were all part of a secondary wave of expansion. Communities who had been incorporated into the empire in previous conflicts, as well as neighbours eager to settle old scores, gave the invading force convenient passage through their territories toward the crisis on the new periphery, and they were put to good use as carriers, road builders and even soldiers. ${ }^{71}$ Furthermore, the communities still hostile to the coloniser, those to whom the current campaign was to serve as an example and warning (the Egba in the case of the Ijebu and the Venda in the case of the Hananwa) did not join in the fighting. This certainly must have made it a lot easier for the Boers, as it did for the British, to make their Maxim guns do the work.

\section{Aftermath: the need for a memory}

The social memory of the military subjugation of African communities reveals that, the fact that the Africans lost, was less important than the knowledge that they had offered courageous resistance. In all the cases referred to in this paper, the defeat on the battlefield was converted not into a memory of humiliation, but a landmark representing the pride and courage of a people and the defiance of their leaders. The story of resistance, rather than defeat, nourished the African imagination and provided the yarn for weaving an identity. ${ }^{72}$

66. TA: SS. 4700, R.2004/95: Verslag of Algemeen Overzicht van den Commandant-Generaal van den gevoerden krijg tegen de oproerige kafferstammen van Malaboch (te Blauwberg), Seleboel, Magoeba, Mahoepa en anderen, wonende in die Lage Velden van het district Zoutpansberg, p. 7.

67. R. Smith, 'Nigeria-Ijebu' in M. Crowder (ed.) West African resistance. The military response to colonial occupation (London, 1971), p. 192; O. Ikime, 'Nigeria-Ebrohimi' in M. Crowder (ed.) West African resistance. The military response to colonial occupation (London, 1971), pp. 215-216; pp. 226 \& 228 .

68. The Press, 1894-06-23.

69. The Press, 1894-07-03.

70. C. Sonntag, My friend Maleboch ..., pp. 76, 98 \& 101.

71. R. Smith, 'Nigeria-Ijebu' in M. Crowder (ed.) West African resistance. The military response to colonial occupation (London, 1971), pp. 182-183; O. Ikime, 'Nigeria-Ebrohimi' in M. Crowder (ed.) West African resistance. The military response to colonial occupation (London, 1971), p. 222; C. Rae, Malaboch (Cape Town, 1898), p. 51; C. Sonntag, My friend Maleboch ..., p. 98.

72. A similar tendency would be observed in the Afrikaner's collective memory of their war (1899-1902) against Britain. Boer War stories celebrating the courage and cunning of Boer fighters who captured 
It is in the way the campaigns and the heroes of the late nineteenth century wars are remembered, that this unsuccessful African resistance is absolved of its futility. Had Mmalebôhô submitted to the Boers peacefully in 1894, he would probably, if remembered at all, have been regarded as a collaborator who had sold out his people to an invading force. His resistance, although a failure, provided a starting point for a story of continued resistance.

The Hananwa community is not unique in this experience. Terrence Ranger's contemplation of the significance of the Hehe of modern Tanzania's ill-fated attempt at resisting German imperialism - also in 1894, and his comment on an earlier observation by historians Oliver and Fage, have significance for a broader understanding of resistance memories. ${ }^{73}$. According to Ranger, "[t]he Wahehe of Tanzania seem to be a perfect example of a people broken by futile resistance. They were crushed by military might. They did not even achieve a negotiated peace. Defeat left the people in a desperate state. ..."74 What Ranger remarks here of the Hehe, may just as well have been said of the Hananwa. The Hananwa leaders were imprisoned (without trial) in Pretoria, their enemies were encouraged by Boer officials to hunt down the die-hards who persisted in staying on in their former mountain stronghold; drought and rinderpest contributed further to the hardship caused by the destruction of crops and homesteads during the war. ${ }^{75}$

However, Ranger continues:

...memories of their [Hehe] resistance dominated subsequent German and Wahehe thinking alike. Partly because of pride in these memories Wahehe institutions, or more likely a Wahehe sense of identity, survived so well that Uhehe became the site of the most successful Tanganyikan experiment in indirect rule. Both the Germans and the British felt respect for the Wahehe, so that in later years Wahehe institutions were taken especially seriously ... ${ }^{76}$

In these respects the Hehe rather resemble the Ijebu than the Hananwa. According to Robert Smith, after their defeat, the Ijebu "enthusiastically" embraced Christianity, and along with it, Western education. ${ }^{77}$ The Hananwa were also more susceptible to Christian teaching after the war, but it did not bring them the same benefits as the Ijebu, who contributed to insuring an influential position for the Yoruba in the politics and trade of the new British protectorate and eventually in Nigeria. Boer officials had little respect for Hananwa institutions and even though the Hananwa supported the British during the Anglo-Boer War, as Tlou Makhura vividly summarises it, "they became pyrrhic victors and ultimate victims of

British ammunition convoys and managed to creep in and out of British camps unsighted, captured the imagination of Afrikaner children. In the light of these adventures, the Boer defeat became an undeserved afterthought.

73. A. Adu Boahen (ed.), General history of Africa VII. Africa under colonial domination 1880-1935 (Paris, 1990), p. 75. The Hehe capital was captured by the Germans in 1894. Unlike Mmalebôhô, who was captured, Mkwawa escaped and eventually committed suicide in order to avoid capture. Both are remembered as heroes in their respective communities.

74. T.O. Ranger, 'African reaction to the imposition of colonial rule in East and Central Africa' in R.O. Collins (ed.), Problems in the history of colonial Africa, 1860-1960 (Englewood Cliffs, 1970), p. 77.

75. T.J. Makhura, "The softening of the Baitsweng": post-war reconstruction and development of the Bagananwa society in the Northern Transvaal, 1895-1910' (Revised, unpublished version of a paper presented at the 16th biennial conference of the South African Historical Society, 6-9 July 1997, University of Pretoria).

76. T.O. Ranger, 'African reaction to the imposition of colonial rule in East and Central Africa' in R.O. Collins (ed.), Problems in the history of colonial Africa, 1860-1960 (Englewood Cliffs, 1970), p. 77.

77. R. Smith, 'Nigeria-Ijebu' in M. Crowder (ed.) West African resistance. The military response to colonial occupation (London, 1971), p. 194. 
[this] war."78 In the Peace Treaty of 1902 the cause of South Africa's black communities was sacrificed for the sake of Boer-British reconciliation. But even in this disillusioned state, a "Hananwa sense of identity" did indeed survive.

To get back to Ranger's argument:

Oliver and Fage tell us that for the African peoples the most important factor at this stage of colonial history was ... the intangible psychological issue of whether any given society or group was left feeling that it had turned the colonial occupation to its own advantage, or alternatively that it had been humiliated.

The Wahehe can hardly be said to have turned the early colonial situation to their profit, but they did not come out with a sense of humiliation. 'Today all Wahehe idolize Mkwawa,' wrote a British district officer in the early Mandatory period. "This may be because he actually beat the white man in battle." $" 79$

These memories of Mkwawa reminds one of the Afrikaner legends around an AngloBoer War figure like Christian de Wet. In such idolization it is of no importance that Mkwawa and De Wet were eventually also defeated by the British. The defiant spirit of the individual is what sooths the defeated community and what they, consequently, choose to remember.

To their Itsekiri and Hananwa descendants respectively, Nana and Mmalebôhô also represented such a figure. According to Obaro Ikime, Nana and the Itsekiri were beaten, but not disgraced. Although trailed and exiled after he had fled and eventually surrendered himself to the British in 1894, Nana, then a man in his fifties, was allowed to return to Ebrohimi in 1906. "For the ten more years of his life that were left to him, he demonstrated that he had not lost all the drive, energy and organisation that had won him a trading empire and the envy and hatred of lesser Itsekiri men and ambitious British empire builders. He died on 3 July 1916." 80

Mmalebôhô was never tried by the Boers, but he and his advisers spent almost six years in the Pretoria Gaol. Ironically, in this case, the Brits were the saviours: they released the Hananwa leaders when they occupied Pretoria in 1900. Returning to Blouberg, Mmalebôhô reassumed his position as Hananwa leader. His influence in the region over the following four decades, was such that, upon his death in 1939, it gained him a deferential obituary in the Afrikaans family magazine Die Huisgenoot. ${ }^{81}$ Although Mmalebôhô was eventually absorbed into Afrikaner heritage in the memory of a worthy adversary, he remained first and foremost a symbol of dignity and defiance in Hananwa, specifically 'chiefly', collective memory. At a political rally held at the Blouberg in 1989, the recital of Mmalebôhô's praise poem was recorded by anthropologist Johnny van Schalkwyk and his assistant S.M. Moifatswane. In the context of homeland politics of the former Lebowa, the poem was recited to remind homeland leaders with no links to the traditional aristocracy, that if they were looking for Hananwa support, they had to recognise the importance role

78. T.J. Makhura, 'The softening of the Baitsweng' ..., p. 16.

79. T.O. Ranger, 'African reaction to the imposition of colonial rule in East and Central Africa' in R.O. Collins (ed.), Problems in the history of colonial Africa, 1860-1960 (Englewood Cliffs, 1970), p. 77.

80. O. Ikime, 'Nigeria-Ebrohimi' in M. Crowder (ed.) West African resistance. The military response to colonial occupation (London, 1971), p. 228.

81. G.H.Franz, 'Mmalebogo', Die huisgenoot 23(881), 1939-02-10. pp. 89. 
traditional leaders, like Mmalebôhô, had played in the sustenance of the Hananwa as a community. ${ }^{82}$

The case of the Ijebu differs significantly from that of the Hananwa, today an impoverished community who first had to sustain themselves in an Apartheid homeland environment and now set their hopes on Government intervention or tourist initiatives for a more rewarding future. To the Ijebu, who prospered after their colonial war, "the sacrifice and courage of the warriors at Pobo, Majoda and Yemoji [note that author Robert Smith mentions the places, and not the names of the warriors] sometimes seem forgotten" in the new Nigerian order of the 1960s and beyond, " ... and yet, for good or ill, they continue to nourish that sense of political and spiritual identity which binds the Ijebu everywhere." From this description, Ijebu memories of war and heroism seem far more distant in the collective consciousness than in the case of, at least, the Hananwa aristocracy, who still needs the inspiration they can draw from their historical identity. The relative eminence of historical heroes in the collective memory, indeed seems to alter according to a community's needs in the present.

$* * *$

The emphasis in this discussion was on the resemblances between African resistance to Boer and British wars of conquest respectively. Should one wish to highlight the differences and discrepancies in the motivations and levels of hardship and success in the selected examples, one will be guaranteed to find plenty. The similarities in the experiences of colonisers and colonised alike, however, at least urges serious consideration for treating Boer activities in the northern Transvaal during the 1890s against a larger backdrop, that of the European Scramble for Africa.

82. A. Joubert \& J.A. van Schalkwyk, 'War and remembrance: the power of oral poetry and politics of Hananwa identity', Journal of Southern African Studies 25(1), 1999-03-01, p. 30.

83. R. Smith, 'Nigeria-Ijebu' in M. Crowder (ed.) West African resistance. The military response to colonial occupation (London, 1971), p. 194. 